\title{
Regional and temporal variability of sinking organic matter in the subtropical northeast Atlantic Ocean: a biomarker diagnosis
}

\author{
I. J. Alonso-González ${ }^{1}$, J. Arístegui ${ }^{1}$, C. Lee $^{2}$, and A. Calafat ${ }^{3}$ \\ ${ }^{1}$ Facultad de Ciencias del Mar, Universidad de Las Palmas de Gran Canaria, Las Palmas de Gran Canaria, 35017, Spain \\ ${ }^{2}$ School of Marine and Atmospheric Sciences, Stony Brook University, Stony Brook, NY 11794-5000, USA \\ ${ }^{3}$ GRC Geociències Marines, Dep. de Estratigrafia i Paleontologia, Universitat de Barcelona, Barcelona, 08028, Spain
}

Received: 17 October 2009 - Published in Biogeosciences Discuss.: 26 November 2009

Revised: 14 June 2010 - Accepted: 16 June 2010 - Published: 6 July 2010

\begin{abstract}
Sinking particles through the pelagic ocean have been traditionally considered the most important vehicle by which the biological pump sequesters carbon in the ocean interior. Nevertheless, regional scale variability in particle flux is a major outstanding issue in oceanography. Here, we have studied the regional and temporal variability of total particulate organic matter fluxes, as well as chloropigment and total hydrolyzed amino acid (THAA) compositions and fluxes in the Canary Current region, between $20-30^{\circ} \mathrm{N}$, during two contrasting periods: August 2006, characterized by warm and stratified waters, but also intense winds which enhanced eddy development south of the Canary Islands, and February 2007, characterized by colder waters, less stratification and higher productivity. We found that the eddyfield generated south of the Canary Islands enhanced by $>2$ times particulate organic carbon (POC) export with respect to stations (FF; far-field) outside the eddy-field influence. We also observed flux increases of one order of magnitude in chloropigment and 2 times in THAA in the eddy-field relative to FF stations. Principal Components Analysis (PCA) was performed to assess changes in particulate organic matter composition between stations. At eddy-field stations, higher chlorophyll enrichment reflected "fresher" material, while at FF stations a higher proportion of pheophytin indicated greater degradation due to microbes and microzooplankton. PCA also suggests that phytoplankton community structure, particularly the dominance of diatoms versus carbonate-rich plankton, is the major factor influencing the POC export within the eddy field. In February, POC export
\end{abstract}

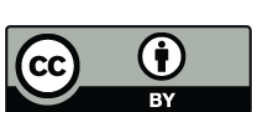

Correspondence to:

I. J. Alonso-González

(ialonso@becarios.ulpgc.es) fluxes were the highest ever reported for this area, reaching values of $\sim 15 \mathrm{mmol} \mathrm{C} \mathrm{m}^{-2} \mathrm{~d}^{-1}$ at $200 \mathrm{~m}$ depth. Compositional changes in pigments and THAA indicate that the source of sinking particles varies zonally and meridionally and suggest that sinking particles were more degraded at near-coastal stations relative to open ocean stations.

\section{Introduction}

Export of organic matter via particles settling out of the euphotic zone is one of the main mechanisms by which atmospheric $\mathrm{CO}_{2}$ can be transported to the deep ocean. Organic matter production and its subsequent cycling by zooplankton and microbes are key processes in carbon export. Several studies suggest that mesoscale features may have a major impact on upper ocean biogeochemistry by enhancing biological activity (Falkowski et al., 1991; Sweeney, 2001; Bidigare et al., 2003; Benitez-Nelson et al., 2007; McGillicuddy et al., 2007). Recently, intense effort has been focused on complex multidisciplinary mesoscale programs, like E-Flux (North Pacific) and EDDIES (EDdy Dynamics, mixing, Export, and Species composition, North Atlantic) to address the role of mesoscale eddies in downward export flux. Surprisingly, both programs concluded that eddies did not enhance carbon flux, although they might increase the flux of biogenic silica (Benitez-Nelson and McGillicuddy, 2008). Moreover, these programs revealed our lack of knowledge about the complex mechanisms that control organic matter export from the euphotic zone within eddies.

Most sediment trap studies have measured bulk properties of the fluxes, such as total carbon and nitrogen, while individual organic compounds have received much less attention.

Published by Copernicus Publications on behalf of the European Geosciences Union. 


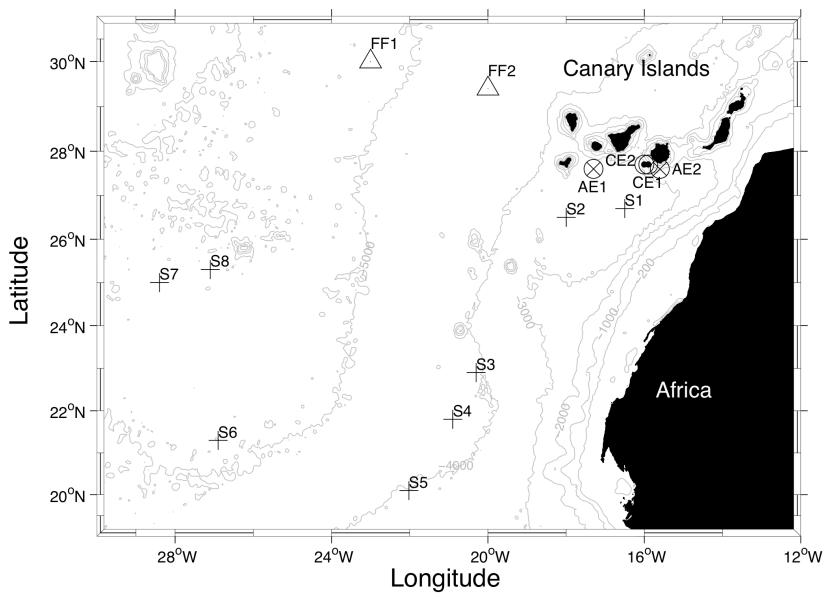

Fig. 1. Map showing the location of the free-drifting sediment trap deployments carried out during August 2006 and February 2007. $\triangle$ far-field, $\otimes$ anticyclonic eddy, $\odot$ cyclonic eddy and $+\mathrm{S}$ stations.

Although total carbon and nitrogen values are useful, knowledge of the specific compounds provides more precise information on lability, interaction with other elements, and mechanisms of degradation (Lee et al., 2000; Sheridan et al., 2002; Ingalls et al., 2006). Unfortunately, there are only a limited number of studies, mainly focused on pigment composition determined in suspended material, that have documented changes in the organic matter composition within mesoscale features (Jeffrey and Hallegraeff, 1980; Olaizola et al., 1993; Rodríguez et al., 2003). More recently, some studies have highlighted the important role of frontal structures on organic matter fluxes by using sediment trap biomarkers in the Alborán Sea (Sánchez-Vidal et al., 2004; Tolosa et al., 2004, 2005) and in the northeast Atlantic Ocean (Goutx et al., 2005).

In this work we report, together with total POC/PON fluxes, mesoscale and regional trends in amino acid (THAA) and chloropigment compositions and fluxes obtained from free floating sediment trap deployments in the northeast Atlantic Ocean. Both THAA and chloropigments are useful indicators of decomposition, source and transport in the water column (e.g., Wakeham et al., 1997; Dauwe and Middelburg, 1998; Lee et al., 2000). Amino acids are structural components of proteins, making up a major fraction of characterized carbon in marine particulate matter (Lee et al., 2004). Since inorganic nitrogen can control the biological pump through its role as a limiting nutrient, the decomposition and remineralization of organic nitrogen as amino acids are of particular importance. Chloropigments are key indicators of organic matter diagenesis, since their origin stems from surface water communities. By following chlorophyll degradation as particles fall from the surface through the water column we can determine the "freshness" of organic matter during its transport to deeper layers.
Our study was conducted during two different periods of the year: (i) August 2006 (cruise RODA I), characterized by warm and stratified waters, but also intense winds which enhanced eddy development south of the islands, and (ii) February 2007 (cruise RODA II), characterized by colder waters and less stratification. RODA I was planned to evaluate the role of the Canary eddy field in the enhancement of organic matter fluxes. RODA II was designed to look at the spatial variability in the Canary Current region, between $20-30^{\circ} \mathrm{N}$, during the time of the year when primary production is highest (Arístegui et al., 2001; Hernández-León et al., 2007). We hypothesized (1) that organic matter fluxes would be more intense during the most productive season (February), increasing towards the upwelling region, and (2) that eddies south of the Canary Islands would induce changes in organic matter composition, as well as the enhancement of fluxes, compared with waters outside the eddy field.

\section{Methods}

\subsection{Locating mesoscale eddies}

Before the sediment traps were deployed, eddy features in the Canary Current region were identified by satellite sea-surface temperature (AVHRR) images. Once the approximate location was obtained, high-resolution expendable bathythermograph (XBT) transects were carried out to determine the thermal gradients of the mesoscale eddy field. Four eddies were selected for this study: two anticyclonic (AE1 and AE2) and one cyclonic, (CE1) during RODA I and one cyclonic (CE2) during RODA II (Fig. 1, Table 1). Hydrographic sections across the selected eddies were performed to determine the exact location of the eddy core. Conductivity, temperature and depth were recorded with a SeaBird 911+CTD; temperature and pressure sensors were calibrated by the manufacturer just before the cruise. The fluorescence signal of in vivo chlorophyll $a(\operatorname{chl} a)$ was measured with a Seapoint sensor.

\subsection{Sample collection}

Sinking particles were collected from $150 \mathrm{~m}$ depth at three eddy and two far-field (FF; outside eddy-field influence) stations during RODA I and from $200 \mathrm{~m}$ depth at CE2 and 8 non-eddy stations (S1-S8) southwestward of the eddy field, during RODA II (Table 1, Fig. 1). We used a free-drifting multi-trap array holding 8 cylinders $(9 \mathrm{~cm}$ diameter: $50 \mathrm{~cm}$ length and $0.005 \mathrm{~m}^{2}$ collection area), similar to the model described by Knauer et al. (1979). $\mathrm{NaCl}\left(\sim 45 \mathrm{~g} \mathrm{~L}^{-1}\right.$; analytical reagent-grade) was added to increase the salinity inside the traps. No poisons were used to retard bacterial decomposition during the deployment. Upon recovery $(24 \mathrm{~h}$ after deployment), samples were visually checked and all fluid from each cylinder filtered onto pre-combusted $\left(450^{\circ} \mathrm{C}\right.$, $12 \mathrm{~h}) 25 \mathrm{~mm}$ Whatman GF/F filters. Swimmers were rarely present, but if so were processed in the laboratory according 
to the procedure described by Heussner et al. (1990). Large swimming organisms were removed by wet sieving through a $1 \mathrm{~mm}$ nylon mesh, while organisms $<1 \mathrm{~mm}$ were handpicked under a microscope with fine-tweezers. The filters were wrapped in pre-combusted aluminum foil and frozen at $-20^{\circ} \mathrm{C}$ until processing. One filter (corresponding to the filtration of 1 or 2 cylinders) was analyzed for POC/PON and one for chloropigments and amino acids in all samples except for CE2.

\subsection{POM analysis}

In the laboratory, filters for particulate organic carbon (POC) and nitrogen (PON) analysis were thawed and dried overnight at $60^{\circ} \mathrm{C}$, then placed overnight in a desiccator saturated with $\mathrm{HCl}$ fumes, dried again for $24 \mathrm{~h}$ in a second desiccator with silica gel and packed in ultra clean nickel sleeves. The carbon analyses were carried out on a Perkin-Elmer 2400 CHN elemental analyzer (UNESCO, 1994). The DOC adsorption onto GF/F filters was subtracted from samples to avoid the overestimation of POC (Turnewitsch et al., 2007). DOC adsorption onto the filters ranged from $0.3-1.6 \mu \mathrm{mol} C$ per $25 \mathrm{~mm}$ diameter GF/F filter (less than $3.5 \%$ of the POC signal), similar to the blanks reported by Moran et al. (1999) and Turnewitsch et al. (2007).

\subsection{Pigment analysis}

Chloropigments (chlorophyll $a$, pheophytin $a$, pheophorbide $a$ and pyropheophorbide $a$ ) and fucoxanthin were determined using reverse-phase High Performance Liquid Chromatography (HPLC) as described in Lee et al. (2000). Pigments were extracted with $100 \%$ acetone and sonicated for $10 \mathrm{~min}$. The tube containing the filter was centrifuged for 7 min at 3000 r.p.m., and the supernatant collected. Each sample was extracted twice because a third extract contains less than $1 \%$ of the total pigment content (Sun et al., 1991). Combined extracts were filtered through $0.2 \mu \mathrm{m}$ Phenomenex nylon membrane filters and stored at $-20^{\circ} \mathrm{C}$ prior to pigment analysis. The filtered extract was diluted $20 \%$ with MilliQ water and injected onto a 5- $\mu \mathrm{m}$ Alltima C-18 column $(250 \mathrm{~mm} \times 4.6 \mathrm{~mm}$ i.d.). Detection was accomplished with a Shimadzu RF-551 fluorescence detector using an excitation wavelength of $440 \mathrm{~nm}$ and an emission wavelength of $660 \mathrm{~nm}$ and with a Shimadzu SPD-6AV UV absorbance detector using a wavelength of $446 \mathrm{~nm}$. Retention times and chloropigment and fucoxanthin concentrations were determined by comparison of sample peaks with authentic pigment standards (chl $a$ : Turner Design; fucoxanthin: DHI Water and Environment; pheophorbide- $a$ : Porphyrin Products; pheophytin- $a$ and pyropheophorbide- $a$ : synthesized from purified chl $a$ and analyzed spectrophotometrically after King, 1993). Duplicate analyses of the same extract agreed within $10 \%$.
Table 1. RODA drifting traps characteristics: type and station locations and depths of deployment. Time of sediment trap deployment was $24 \mathrm{~h}$ for both cruises. AE: anticyclonic eddy; CE: cyclonic eddy; FF: Far-field station.

\begin{tabular}{llc}
\hline \multicolumn{3}{c}{ RODA I Cruise (August 2006) } \\
\hline Station & Type & $\begin{array}{c}\text { Depth of } \\
\text { deployment }(\mathrm{m})\end{array}$ \\
\hline FF1 $\left(30^{\circ} \mathrm{N}, 23^{\circ} \mathrm{W}\right)$ & Far-field & 150 \\
FF2 $\left(29.4^{\circ} \mathrm{N}, 20^{\circ} \mathrm{W}\right)$ & Far-field & 150 \\
AE1 $\left(27.6^{\circ} \mathrm{N}, 17.3^{\circ} \mathrm{W}\right)$ & Eddy & 150 \\
AE2 $\left(27.6^{\circ} \mathrm{N}, 15.6^{\circ} \mathrm{W}\right)$ & Eddy & 150 \\
CE1 $\left(27.7^{\circ} \mathrm{N}, 16^{\circ} \mathrm{W}\right)$ & Eddy & 150 \\
\hline \multicolumn{2}{c}{$\mathrm{RODA} \mathrm{II} \mathrm{Cruise}$ (February 2007$)$} \\
\hline CE2 $\left(27.7^{\circ} \mathrm{N}, 16.7^{\circ} \mathrm{W}\right)$ & Eddy & 200 \\
S1 $\left(26.7^{\circ} \mathrm{N}, 16.5^{\circ} \mathrm{W}\right)$ & Transect & 200 \\
S2 $\left(26.5^{\circ} \mathrm{N}, 18^{\circ} \mathrm{W}\right)$ & Transect & 200 \\
S3 $\left(22.9^{\circ} \mathrm{N}, 20.3^{\circ} \mathrm{W}\right)$ & Transect & 200 \\
S4 $\left(21.8^{\circ} \mathrm{N}, 20.9^{\circ} \mathrm{W}\right)$ & Transect & 200 \\
S5 $\left(20.1^{\circ} \mathrm{N}, 22.02^{\circ} \mathrm{W}\right)$ & Transect & 200 \\
S6 $\left(21.3^{\circ} \mathrm{N}, 26.9^{\circ} \mathrm{W}\right)$ & Transect & 200 \\
S7 $\left(25^{\circ} \mathrm{N}, 28.4^{\circ} \mathrm{W}\right)$ & Transect & 200 \\
S8 $\left(25.3^{\circ} \mathrm{N}, 27.1^{\circ} \mathrm{W}\right)$ & Transect & 200 \\
\hline
\end{tabular}

\subsection{Amino acid analysis}

Amino acids were measured on the same filters analyzed for pigments; this was accomplished by HPLC using precolumn $o$-pthaldialdehyde (OPA) derivatization after hydrolysis (Lindroth and Mopper, 1979; Lee and Cronin, 1982; Lee et al., 2000). Acetone-extracted filters were sealed in glass tubes under $\mathrm{N}_{2}$ with $6 \mathrm{~N} \mathrm{HCl}$ plus $0.25 \%$ phenol and hydrolyzed for $20 \mathrm{~h}$ at $110^{\circ} \mathrm{C}$. Acid hydrolyzates were filtered through $0.2 \mu \mathrm{m}$ membrane filters and stored at $-20^{\circ} \mathrm{C}$ prior to amino acid analysis. An acid extract aliquot was transferred to a combusted glass vial, evaporated under $\mathrm{N}_{2}$, and dissolved in 60\% MilliQ water: $40 \%$ methanol. A Waters $4 \mu \mathrm{m}$ Nova Pack C-18 $150 \mathrm{~mm} \times 3.9 \mathrm{~mm}$ i.d. column equipped with a guard column was eluted at a flow rate of $1 \mathrm{ml} / \mathrm{min}$. Mobile phases used in the gradient elution consisted of solvent A: $0.05 \mathrm{M}$ sodium acetate $(\mathrm{pH}$ 5.7) and 5\% THF and solvent B: $80 \%$ methanol and $20 \%$ acetone. The program used was $44 \% \mathrm{~B}$ to $53 \% \mathrm{~B}$ in $30 \mathrm{~min}$, then to $100 \% \mathrm{~B}$ in $38 \mathrm{~min}$. OPA-derivatized amino acids were detected by fluorescence (excitation $\lambda=330 \mathrm{~nm}$; emission $\lambda=418 \mathrm{~nm}$ ) and identified by retention time. Peak areas were converted to concentrations using response factors calculated using authentic standards. Standards used included a commercial amino acid standard mixture (Pierce Chemical, Standard $\mathrm{H}$ ) with ornithine, $\beta$-alanine and $\gamma$-aminobutyric acid (Sigma Chemical) added. Duplicate analyses of the same hydrolyzate agreed within 10-15\%. 


\section{Potential temperature $\left({ }^{\circ} \mathrm{C}\right)$}
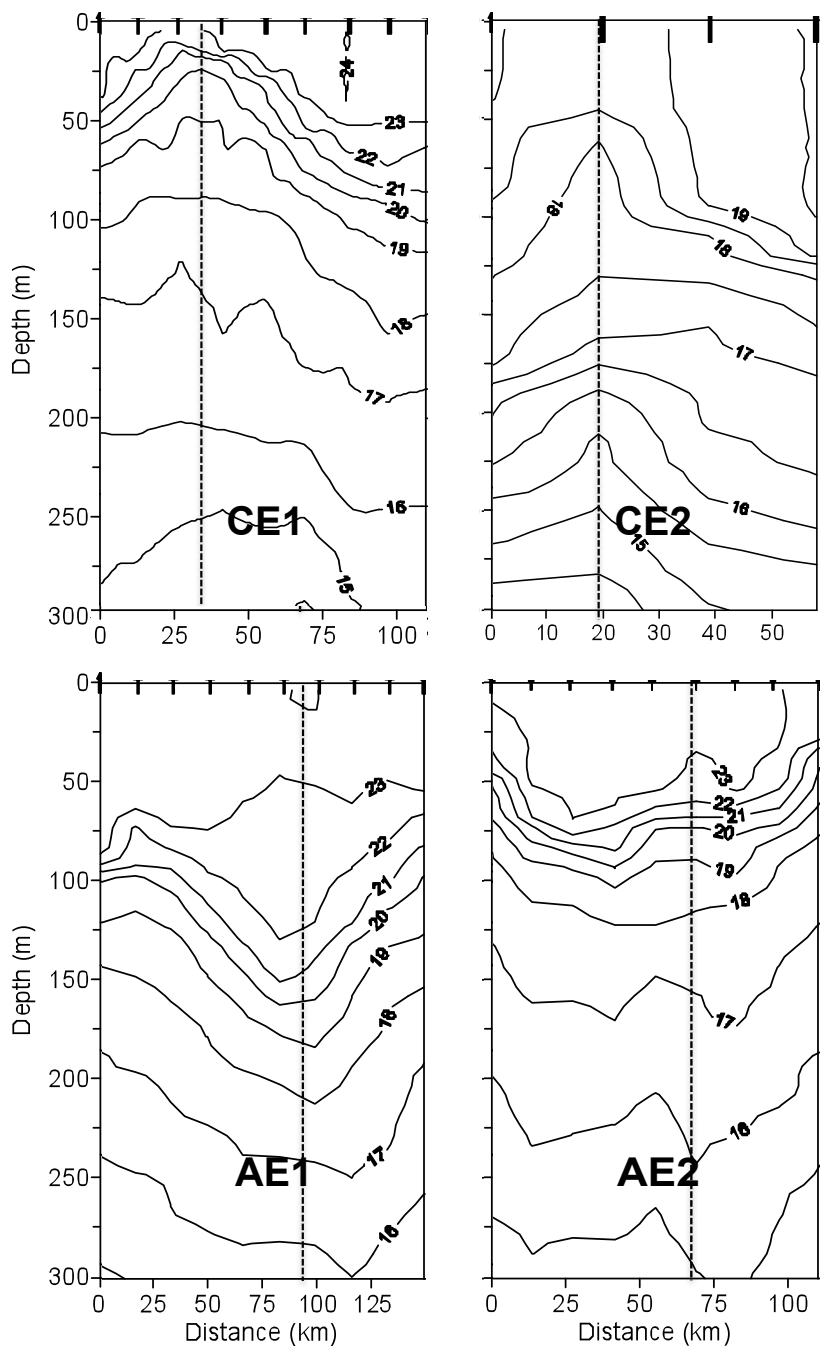

Fig. 2. Vertical distribution of potential temperature across eddies CE1, CE2, AE1 and AE2. Ticks on the top axis represent XBT stations. Dashed lines indicated stations where sediment traps were deployed, coinciding with the location of the eddy core

\subsection{Statistical analyses (PCA)}

Principal Components Analysis (PCA) is commonly used in the analysis of complex organic datasets (Goñi et al., 2000; Ingalls et al., 2006; Goutx et al., 2007). It is a multivariate regression analysis that reduces a large number of variables to a few principal components. PCA was used here to quantitatively assess variation in the organic composition of sinking particles that were collected at eddy stations and over a range of latitudes. PCA was applied to pigment and THAA composition data. Prior to performing PCA, abundance data in mole $\%$ from each sample were standardized by subtracting the mean of all values and dividing by the standard deviation of all values (Dauwe and Middelburg, 1998; Dauwe et al.,
1999; Sheridan et al., 2002). The first PCA principal component is the axis of maximum variation in the data set while the second one is equivalent to the axis of maximum residual variation. A "loading" (variable's contribution to the data set variability) and a "site score" (distance of the sample from the first principal component axis) are calculated for each variable and sample respectively. All PCA were carried out on Sirius for Windows ${ }^{\mathrm{TM}}$ Pattern Recognition System (version 7.0).

\section{Results}

\subsection{Oceanographic settings}

The vertical thermal structure across selected eddies revealed a clear upward (cyclonic) and downward (anticyclonic) perturbation of both the seasonal and main thermoclines (Fig. 2). The $18^{\circ} \mathrm{C}$ isotherm shoaled $\sim 65 \mathrm{~m}$ at $\mathrm{CE} 1$ and $\sim 70 \mathrm{~m}$ at CE2 over horizontal scales of 70 and $20 \mathrm{~km}$, respectively. On the contrary, AE1 and AE2 indicated depression of the $18^{\circ} \mathrm{C}$ isotherm of 70 and $30 \mathrm{~m}$, respectively. Figure 3 displays the vertical profiles of potential temperature and fluorescence at all stations sampled. Deeper mixed layers (125$165 \mathrm{~m}$ ) were found in February as a result of winter cooling, while shallower mixed layers $(<50 \mathrm{~m})$ were observed in August, a period of warmer surface temperature (Fig. 3a and b). In August, the CE1 station, a cold-core cyclonic eddy, exhibited the lowest temperature values ranging from $22.8^{\circ} \mathrm{C}$ at surface to $15.5^{\circ} \mathrm{C}$ at $200 \mathrm{~m}$, whereas the warmest temperatures were observed at the warm-core of the anticyclonic eddy $\mathrm{AE} 1$ ranging from $24^{\circ} \mathrm{C}$ at surface to $18^{\circ} \mathrm{C}$ at $200 \mathrm{~m}$ (Fig. 3a). A counterintuitive cold signature in surface waters at AE2 was due to cold water encroachment from a nearby filament. In February, water temperatures were lower at coastal stations (S1, S2, S3, S4 and S5) than at the openocean stations (S6, S7 and S8), indicative of the influence of the nearby coastal upwelling (Fig. 3b). The lowest temperature in the upper $75 \mathrm{~m}$ was found at CE2. Below the mixed layer, all stations were strongly stratified.

The deep fluorescence maximum (DFM) in August was located between 100-125 $\mathrm{m}$ in the far-field (FF) stations, shoaling to $\sim 50 \mathrm{~m}$ at $\mathrm{AE} 2$ and $\mathrm{CE} 1$ stations, where fluorescence was $>0.8$ volts (Fig. 3c). AE1 exhibited an intermediated situation with a DFM at $75 \mathrm{~m}$ reaching 0.6. In February, the highest surface fluorescence values along the $\mathrm{S}$ stations were found at the coastal stations S3, S4 and S5, and were 2 to 3 times higher than at open ocean stations (Fig. 3d). The only eddy station sampled during February (CE2) showed an extremely high fluorescence signal ( $>2$ volts) between surface and $150 \mathrm{~m}$. 
a)

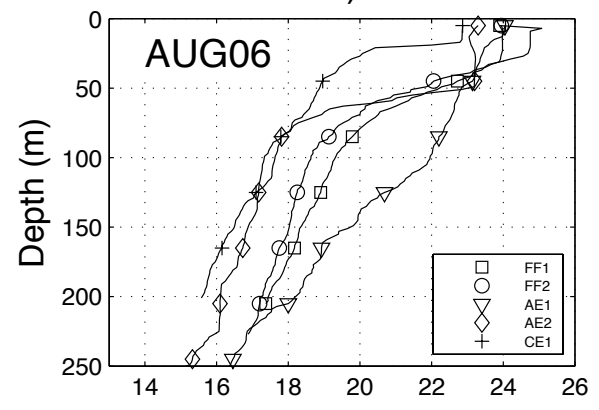

b)

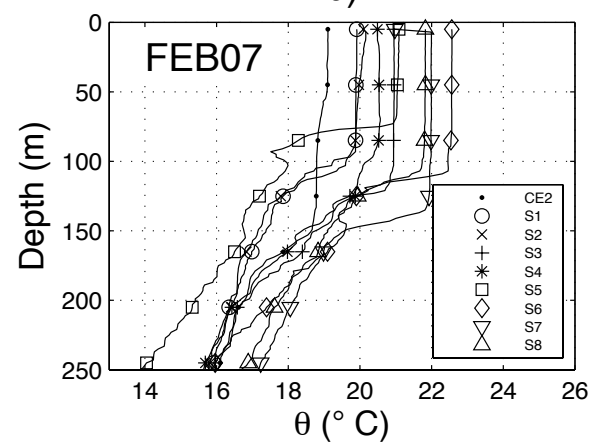

c)

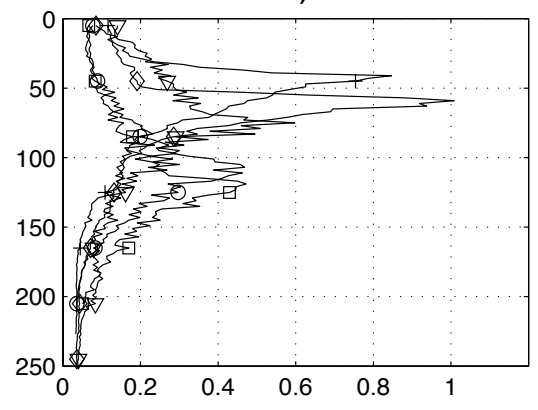

d)

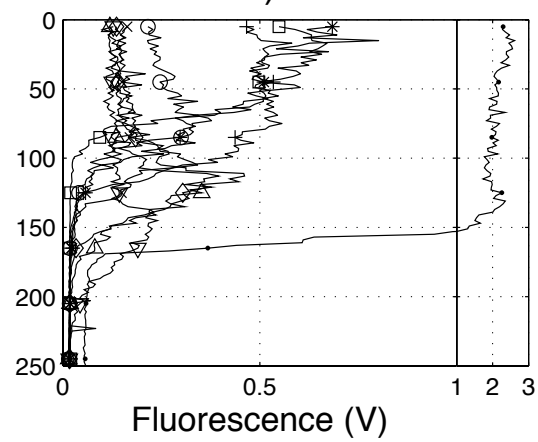

Fig. 3. Depth profiles of potential temperature - (a) and (b) - and fluorescence - (c) and (d) - at eddy-field, far-field (FF) and S stations.

\subsection{Sinking POM fluxes}

At all three eddy stations sampled during August 2006, the POC and PON fluxes at $150 \mathrm{~m}$ were higher than at FF stations (Fig. 4a). POC fluxes ranged from an average value of $5.8 \pm 0.3 \mathrm{mmol} \mathrm{C} \mathrm{m}^{-2} \mathrm{~d}^{-1}$ at $\mathrm{FF}$ stations to $9.7 \pm 2.0 \mathrm{mmol} \mathrm{C} \mathrm{m}^{-2} \mathrm{~d}^{-1}$ at eddy stations ( $\sim 67 \%$ higher). PON fluxes were calculated to be $0.8 \pm 0.05 \mathrm{mmol} \mathrm{N} \mathrm{m}^{-2} \mathrm{~d}^{-1}$ within the eddy cores relative to $0.4 \pm 0.007 \mathrm{mmol} \mathrm{N} \mathrm{m}^{-2} \mathrm{~d}^{-1}$ at the FF stations (two times higher at eddy-field versus FF stations). POC flux within the CE2 eddy core (February 2007) was extremely high $\left(28.5 \mathrm{mmol} \mathrm{C} \mathrm{m}^{-2} \mathrm{~d}^{-1}\right)$ : 2.3 fold higher than other stations, including S3, S4 and S5, which were close to the coastal upwelling. PON flux within the CE2 eddy was $1.1 \mathrm{mmol} \mathrm{N} \mathrm{m}^{-2} \mathrm{~d}^{-1}$ at $200 \mathrm{~m}$; approximately the same magnitude as stations south of the Canary Islands (S1 and S2), but lower than stations affected by the upwelling (S3-S5). Molar C/N ratios in August ranged from $8.2 \pm 2$ at eddy-field stations to $14.1 \pm 0.7$ at FF stations, always higher than the Redfield ratio $(\mathrm{C} / \mathrm{N}=6.6)$. The lowest value $(\mathrm{C} / \mathrm{N}=8.2)$ was observed at the $\mathrm{CE} 1$ eddy station. In February, C/N ratios were lower (5.5-10.3), except at eddy $\mathrm{CE} 2$, which exhibited an extremely high $\mathrm{C} / \mathrm{N}$ ratio $(\mathrm{C} / \mathrm{N}=32)$.

Substantial temporal variability in $\mathrm{POC}$ and $\mathrm{PON}$ fluxes was found when comparing the two study periods (Fig. 4a and b). POC and PON fluxes were about 2 times higher in February $\left(8.3-28.5 \mathrm{mmol} \mathrm{C} \mathrm{m}^{-2} \mathrm{~d}^{-1}\right.$; $\left.1.1-2.6 \mathrm{mmol} \mathrm{N} \mathrm{m}^{-2} \mathrm{~d}^{-1}\right)$ than in August (5.5$\left.13.1 \mathrm{mmol} \mathrm{C} \mathrm{m}^{-2} \mathrm{~d}^{-1} ; \quad 0.4-0.8 \mathrm{mmol} \mathrm{N} \mathrm{m}^{-2} \mathrm{~d}^{-1}\right)$. The mean $\mathrm{C} / \mathrm{N}$ ratio in February samples was Redfieldian (6.6 \pm 1.9 , excluding the CE2 station), while in August it was $11.6 \pm 2.9$ (including eddy stations).

The regional variability in POC and PON fluxes was characterized by high fluxes and low $\mathrm{C} / \mathrm{N}$ ratios $(6.7 \pm 0.16)$ at stations affected by upwelling (S3-S5) and lower (30-35\% less) POC and PON fluxes at stations S2, S6 and S8. Surprisingly, fluxes at the oceanic station S7 were comparable to the more coastal stations. S1, located south of the Canaries, exhibited a high POC and PON fluxes and also a high $\mathrm{C} / \mathrm{N}$ ratio (Fig. 4b).

\subsection{Pigment fluxes and composition}

Table 2 shows the variability in pigment fluxes and composition between eddy-field and FF stations. Pigment fluxes ranged over an order of magnitude from 35 to $322 \mu \mathrm{g} \mathrm{m}^{-2} \mathrm{~d}^{-1}$ (Table 2). They were 4 to 9-fold greater at the eddy-field stations, with an average value of $224 \mu \mathrm{g} \mathrm{m}^{-2} \mathrm{~d}^{-1}$, compared to the FF stations (average value $35.3 \mu \mathrm{g} \mathrm{m}^{-2} \mathrm{~d}^{-1}$ ). Among eddy-field stations, pigment fluxes in anticyclonic AE1 and AE2 eddies were higher than in the cyclonic eddy CE1.

Differences in chloropigment composition were also found between eddy-field and FF stations (Table 2). 

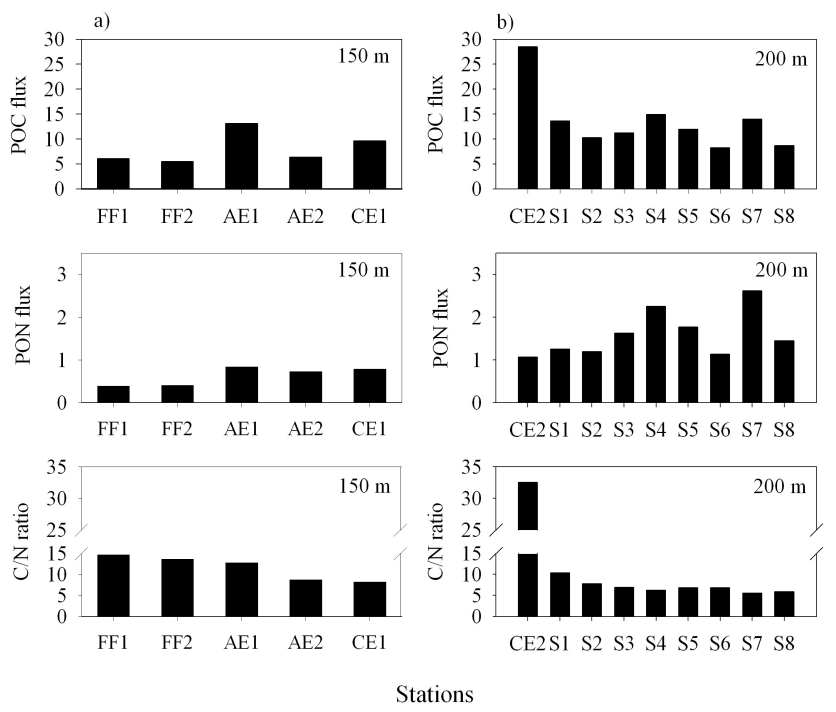

Fig. 4. (a) $\mathrm{POC}$ and $\mathrm{PON}$ fluxes $\left(\mathrm{mmol} \mathrm{m}^{-2} \mathrm{~d}^{-1}\right)$ and $\mathrm{C} / \mathrm{N}$ ratios at eddy-field and far-field stations; (b) POC and PON fluxes $\left(\mathrm{mmol} \mathrm{m}{ }^{-2} \mathrm{~d}^{-1}\right)$ and $\mathrm{C} / \mathrm{N}$ ratios at $\mathrm{S}$ stations.

The mole\% of chl $a$, fucoxanthin, and chlorophyll degradation products (pheophytin- $a$, pheophorbide- $a$ and pyropheophorbide- $a$ ), were calculated to examine the role of eddy-field stations in phytoplankton generation and degradation (see Table 3 for references). Chl $a$ was the major chloropigment present at all eddy-field stations making up an average of $88 \pm 12$ mole $\%$ of pigments measured, while pheophytin- $a$ dominated FF stations. Pheophorbide- $a$ was present in small amounts at anticyclonic eddy AE2, suggesting a low zooplankton grazing activity (Shuman and Lorenzen, 1975; Ziegler et al., 1988). Pyropheophorbide- $a$ ranged from 0.08 to 3.43 mole\% at AE1 and FF1, respectively. Fucoxanthin was not detectable in these samples probably it could have been a detection problem due to sample size. Extensive degradation of pigments may also have been responsible for the near absence of fucoxanthin in these samples (Ingalls et al., 2006).

Considerable variability in pigment fluxes was found when comparing the two periods of study. Average total pigment fluxes were $\sim 6$-fold higher in February $\left(838 \pm 502 \mu \mathrm{g} \mathrm{m}^{-2} \mathrm{~d}^{-1}\right)$, when primary production is known to peak (Arístegui et al., 2001; Hernández-León et al., 2007), compared to August (Table 4). Important variability in chloropigment composition between August and February was also found. Chl $a$ was highest at all stations during the February cruise and at the eddy-field stations in August, while pheophytin- $a$ dominated FF stations during the August cruise. Chloropigment compositions in February samples and August eddy-field samples were similar.

Chloropigment fluxes vary spatially within this region, ranging from 376 (S7) to $1803 \mu \mathrm{g} \mathrm{m}^{-2} \mathrm{~d}^{-1}$ (S4), with enhanced export occurring over the Cape Blanc upwelling
Table 2. Chloropigment fluxes and compositions at $150 \mathrm{~m}$ in sediment trap samples from far-field (FF) and eddy-field stations during August 2006. chl: chlorophyll- $a$; pptn: pheophytin- $a$; ppb: pheophorbide- $a$; pyro: Pyropheophorbide- $a$ : fuco: fucoxanthin. ND- not detected.

\begin{tabular}{lrrrrrr}
\hline \multicolumn{7}{c}{ Fluxes $\left(\mu \mathrm{g} \mathrm{m}^{-2} \mathrm{~d}^{-1}\right)$} \\
\hline Station & chl & pptn & ppb & pyro & fuco & Total \\
\hline FF1 & ND & 35.0 & ND & 0.8 & ND & 35.8 \\
FF2 & ND & 35.1 & ND & ND & ND & 35.1 \\
AE1 & 313.1 & 9.1 & ND & 0.2 & ND & 322.4 \\
AE2 & 163.7 & 47.7 & 3.31 & 1.9 & ND & 216.6 \\
CE1 & 122.9 & 9.5 & ND & 0.1 & ND & 132.5 \\
\hline \multicolumn{7}{c}{ Mole\% } \\
FF1 & ND & 96.57 & ND & 3.43 & ND & \\
FF2 & ND & 100.00 & ND & ND & ND & \\
AE1 & 97.03 & 2.89 & ND & 0.08 & ND & \\
AE2 & 74.16 & 22.17 & 2.26 & 1.41 & ND & \\
CE1 & 92.49 & 7.33 & ND & 0.18 & ND & \\
\hline
\end{tabular}

area (S4 and S5 stations). Lower fluxes were found at the most oceanic stations (S7-S8; Table 4). Differences in the chloropigment composition were also observed in February samples (Table 4). Mole\% chl $a$ was highest at all stations exceeding $80 \%$ (except S3); mole\% pheophytin- $a$ ranged from 2.4 to $96.8 \%$; pheophorbide- $a$ was present in a considerable proportion at S2 and S4, indicative of zooplankton grazing. Mole\% pyropheophorbide- $a$ follows the same trend as pheophorbide- $a$ ranging from 0.08 to 7.16 mole $\%$. Fucoxanthin was only detected at coastal stations S2 and S4.

\subsection{Total hydrolyzable amino acid (THAA) fluxes and composition}

Amino acid export was in general higher (2 times) at eddyfield stations than at FF stations during August (Table 5). Furthermore, individual and total amino acids fluxes also revealed considerable differences between eddy types. $\mathrm{Cy}$ clonic eddy CE1 had a 2-fold higher amino acid flux compared to anticyclonic eddies AE1 and AE2 (Table 5).

Sinking particles had gross amino acid compositions similar to those reported by Lee and Cronin (1984) and Lee et al. (2000) for sinking particles in the Pacific Ocean. Aspartic acid, glutamic acid, serine, glycine and alanine were the most abundant amino acids, although there were differences in amino acid compositions between eddy-field and FF stations, as well as among the different eddies (Table 5). Mole\% of glycine and glutamic acid (except CE1) were enriched at eddy-field stations relative to FF stations. On the other hand, mole $\% \gamma$-aminobutyric acid (only at FF1), histidine and methionine were enriched at FF relative to eddy-field stations. Mole\% aspartic acid, glutamic acid, threonine and alanine 
Table 3. Diagnostic table of amino acid and pigment biomarkers used to examine variation in organic composition of sinking particles collected during the RODA project.

\begin{tabular}{|c|c|c|c|}
\hline Biomarker type & Biomarker abbrevation & Indicator & Reference \\
\hline \multirow[t]{7}{*}{ Amino acids } & Mole \% ASP & $\mathrm{CaCO}_{3}$-organisms & $\begin{array}{l}\text { Degens, 1976; Carter and Mitterer, } \\
\text { 1978; Müller et al., 1986; Lee et al., } \\
\text { 2000; Ingalls et al. } 2003\end{array}$ \\
\hline & Mole\% GLU & & \\
\hline & Mole\% GLY & diatoms & $\begin{array}{l}\text { Hecky et al., 1973; Siezen and } \\
\text { Mague, 1978; Cowie and Hedges, } \\
\text { 1996; Lee et al., } 2000\end{array}$ \\
\hline & Mole\% SER & & \\
\hline & Mole\% THR & & \\
\hline & Mole $\% \beta$-alanine & degradation & $\begin{array}{l}\text { Lee and Cronin, 1982; Cowie and } \\
\text { Hedges, 1994; Ingalls et al., } 2006\end{array}$ \\
\hline & $\begin{array}{l}\text { Mole } \% \gamma \text {-aminobutyric } \\
\text { acid }\end{array}$ & degradation & $\begin{array}{l}\text { Lee and Cronin, 1982; Cowie and } \\
\text { Hedges, 1994; Nguyen and Harvey, } \\
\text { 1997; Ingalls et al., } 2006\end{array}$ \\
\hline \multirow[t]{5}{*}{ Pigments } & Mole\% Chlorophyll & phytoplankton & Jeffrey and Vesk, 1997 \\
\hline & Mole\% & macrozooplankton & Shuman and Lorenzen, 1975; \\
\hline & $\begin{array}{l}\text { pyropheophorbide } \\
\text { Mole\% pheophorbide }\end{array}$ & grazing & Ziegler et al., 1988 \\
\hline & Mole\% pheophytin & $\begin{array}{l}\text { microbial and } \\
\text { microzooplankton } \\
\text { grazing }\end{array}$ & Sun et al., 1993; Lee et al., 2000 \\
\hline & Mole\% fucoxanthin & diatoms & Jeffrey and Vesk, 1997 \\
\hline
\end{tabular}

were enriched in anticyclonic eddies AE1 and AE2 relative to cyclonic eddy $\mathrm{CE} 1$, whereas mole\% of serine and glycine were enriched at cyclonic eddy CE1.

Maximum fluxes of amino acids occurred at the $200 \mathrm{~m}$ traps during February. Total mean fluxes of amino acids ranged from $197 \pm 3.8$ ( $\mathrm{FF}$ stations in August) to $838 \pm 502 \mu \mathrm{mol} \mathrm{m}^{-2} \mathrm{~d}^{-1}$ (February) (Tables 5 and 6). Fluxes also showed marked latitudinal differences, with highest fluxes (1447 and $1657 \mu \mathrm{mol} \mathrm{m}^{-2} \mathrm{~d}^{-1}$ at S3 and S4, respectively) in the Cape Blanc upwelling region. The mean amino acid flux at open ocean stations (S6 and S7) was $976 \pm 167 \mu \mathrm{mol} \mathrm{m}{ }^{-2} \mathrm{~d}^{-1}, \sim 40 \%$ less than the upwelling stations, but $\sim 30 \%$ higher than the more coastal stations S2 and S5 (Table 6).

Small but important spatial and temporal variations in THAA composition were evident (Table 6). S2, S3 and S4 were enriched in aspartic acid relative to S5, S6, S7 and S8. Serine was considerably higher $(9.46 \pm 1.03 \mathrm{~mole} \%)$ in the August samples at all stations than in February where a mean mole\% serine of $6.97 \pm 0.6$ was found. Glycine $(15.52 \pm 1.3 \mathrm{~mole} \%)$ was the most abundant amino acid in all August samples (FF and eddies) and was highest at cyclonic CE1 station (18.49 mole\%). Mole\% glutamic acid and glycine were the most abundant amino acids in all February samples. Non-protein amino acids, $\beta$-alanine and $\gamma$ aminobutyric acid, were present at stations S2, S4, S5 and
Table 4. Chloropigment fluxes and compositions at $200 \mathrm{~m}$ depth obtained from sediment trap samples during February 2007. chl: chlorophyll- $a$; pptn: pheophytin- $a$; ppb: pheophorbide- $a$; pyro: Pyropheophorbide- $a$ : fuco: fucoxanthin. ND - not detected.

\begin{tabular}{|c|c|c|c|c|c|c|}
\hline \multicolumn{7}{|c|}{ Fluxes $\left(\mu \mathrm{g} \mathrm{m}^{-2} \mathrm{~d}^{-1}\right)$} \\
\hline Station & chl & pptn & $\mathrm{ppb}$ & pyro & fuco & Total \\
\hline $\mathrm{S} 2$ & 673.2 & 31.5 & 15.8 & 11.6 & 1.18 & 733.2 \\
\hline S3 & ND & 465.3 & 6.3 & 3.7 & ND & 475.2 \\
\hline $\mathrm{S} 4$ & 1542.8 & 84.5 & 82.7 & 81.5 & 11.04 & 1802.6 \\
\hline S5 & 1046.8 & 91.4 & 4.0 & 2.2 & ND & 1144.4 \\
\hline S6 & 832.8 & 20.5 & 5.3 & 6.0 & ND & 864.5 \\
\hline S7 & 349.8 & 26.2 & ND & ND & ND & 375.9 \\
\hline S8 & 471.0 & ND & ND & 0.2 & ND & 471.2 \\
\hline \multicolumn{7}{|c|}{ Mole\% } \\
\hline $\mathrm{S} 2$ & 89.73 & 4.30 & 3.17 & 2.58 & 0.22 & \\
\hline $\mathrm{S} 3$ & ND & 96.85 & 1.92 & 1.24 & ND & \\
\hline $\mathrm{S} 4$ & 80.94 & 4.55 & 6.53 & 7.16 & 0.81 & \\
\hline S5 & 91.00 & 8.16 & 0.53 & 0.31 & ND & \\
\hline S6 & 95.53 & 2.41 & 0.91 & 1.14 & ND & \\
\hline S7 & 92.87 & 7.13 & ND & ND & ND & \\
\hline S8 & 99.92 & ND & ND & 0.08 & ND & \\
\hline
\end{tabular}


Table 5. Amino acid fluxes and compositions at $150 \mathrm{~m}$ in sediment trap samples from far-field and eddy-field stations during August 2006. AA-C/POC is the contribution of amino acids to the total POC flux. ND - not detected.

\begin{tabular}{|c|c|c|c|c|c|c|c|c|c|c|c|c|c|c|c|c|c|c|c|c|}
\hline \multicolumn{21}{|c|}{ Fluxes $\left(\mu \mathrm{mol} \mathrm{m}{ }^{-2} \mathrm{~d}^{-1}\right)$} \\
\hline Station & ASP & GLU & SER & HIS & GLY & THR & ARG & BALA & ALA & GABA & TYR & MET & VAL & PHE & ILE & LEU & LYS & ORN & Total & $\mathrm{AA}-\mathrm{C} / \mathrm{POC}$ \\
\hline FF1 & 17.3 & 25.9 & 17.2 & 2.6 & 29.5 & 10.8 & 10.1 & ND & 21.6 & 0.6 & 6.4 & 0.9 & 12.3 & 7.6 & 7.5 & 15.5 & ND & 8.7 & 194.5 & 0.14 \\
\hline FF2 & 19.2 & 28.0 & 18.4 & 2.4 & 31.6 & 11.5 & 9.9 & ND & 21.9 & 0.3 & 6.6 & 0.3 & 11.5 & 7.7 & 6.5 & 15.5 & ND & 8.9 & 199.9 & 0.16 \\
\hline AE1 & 23.1 & 34.7 & 29.3 & 4.1 & 50.7 & 13.5 & 14.8 & ND & 25.5 & 0.4 & 9.4 & 2.5 & 14.6 & 10.1 & 9.8 & 21.4 & ND & 12.5 & 276.3 & 0.10 \\
\hline AE2 & 34.4 & 57.4 & 32.7 & 5.0 & 63.1 & 21.8 & 21.3 & ND & 43.2 & 0.7 & 12.2 & 0.7 & 25.8 & 14.8 & 16.1 & 30.1 & 0.5 & 19.1 & 398.9 & 0.28 \\
\hline CE1 & 46.9 & 72.6 & 60.5 & 7.4 & 106.9 & 28.5 & 32.5 & ND & 51.8 & 1.1 & 19.1 & 1.3 & 31.2 & 20.8 & 21.1 & 44.2 & 3.1 & 29.2 & 577.9 & 0.27 \\
\hline \multicolumn{21}{|c|}{ Mole\% } \\
\hline FF1 & 9.28 & 12.90 & 8.86 & 1.32 & 15.17 & 5.53 & 5.21 & ND & 11.12 & 0.31 & 3.31 & 0.47 & 6.33 & 3.92 & 3.85 & 7.97 & ND & 4.45 & & \\
\hline FF2 & 8.86 & 12.56 & 10.59 & 1.46 & 15.33 & 4.88 & 5.37 & ND & 11.23 & 0.14 & 3.40 & 0.89 & 5.77 & 3.67 & 3.54 & 7.76 & ND & 4.53 & & \\
\hline $\mathrm{AE} 1$ & 9.63 & 13.98 & 9.20 & 1.20 & 15.78 & 5.75 & 4.93 & ND & 10.93 & 0.16 & 3.29 & 0.13 & 5.74 & 3.83 & 3.24 & 7.77 & ND & 4.44 & & \\
\hline AE2 & 8.61 & 14.39 & 8.20 & 1.26 & 15.82 & 5.46 & 5.34 & ND & 10.83 & 0.17 & 3.07 & 0.17 & 6.46 & 3.71 & 4.03 & 7.55 & 0.14 & 4.80 & & \\
\hline CE1 & 8.11 & 12.56 & 10.46 & 1.28 & 18.49 & 4.93 & 5.62 & ND & 8.96 & 0.19 & 3.31 & 0.23 & 5.39 & 3.59 & 3.64 & 7.64 & 0.53 & 5.05 & & \\
\hline
\end{tabular}

ASP - aspartic acid; GLU - glutamic acid; SER, serine - HIS, histidine; GLY - glycine; THR - threonine; ARG - arginine; BALA beta-alanine; ALA - alanine; GABA - gamma-aminobutyric acid; TYR - tyrosine; MET - methionine; VAL - valine; PHE - phenylalanine; ILE - isoleucine; LEU - leucine; LYS - lysine; ORN - ornithine.

Table 6. Amino acid fluxes and compositions at $200 \mathrm{~m}$ depth obtained from sediment trap samples during February 2007. AA-C/POC is the contribution of amino acids to the total POC flux. S8 amino acid sample was lost during analysis. See names for amino acids in Table 5. ND - not detected.

\begin{tabular}{|c|c|c|c|c|c|c|c|c|c|c|c|c|c|c|c|c|c|c|c|c|}
\hline \multicolumn{21}{|c|}{ Fluxes $\left(\mu \mathrm{mol} \mathrm{m}{ }^{-2} \mathrm{~d}^{-1}\right)$} \\
\hline Station & ASP & GLU & SER & HIS & GLY & THR & ARG & BALA & ALA & GABA & TYR & MET & VAL & PHE & ILE & LEU & LYS & ORN & Total & $\mathrm{AA}-\mathrm{C} / \mathrm{POC}$ \\
\hline S2 & 72.7 & 102.7 & 55.8 & 9.5 & 106.6 & 48.0 & 35.0 & 1.4 & 95.4 & 1.9 & 22.6 & 3.8 & 48.2 & 27.0 & 27.9 & 55.4 & ND & 41.4 & 755.2 & 0.33 \\
\hline S3 & 166.3 & 197.2 & 96.0 & 21.1 & 177.8 & 88.4 & 73.6 & ND & 178.6 & 0.3 & 40.7 & 10.8 & 90.1 & 51.2 & 51.2 & 104.7 & 2.7 & 96.7 & 1447.9 & 0.58 \\
\hline S4 & 166.4 & 216.0 & 115.2 & 19.4 & 247.5 & 103.2 & 81.7 & 1.2 & 214.2 & 3.6 & 48.5 & 6.4 & 110.4 & 61.4 & 68.3 & 122.4 & 1.6 & 110.3 & 1697.7 & 0.51 \\
\hline S5 & 55.6 & 81.9 & 44.0 & 8.7 & 83.3 & 39.6 & 31.8 & 0.3 & 80.3 & 3.0 & 20.4 & 13.9 & 42.6 & 24.8 & 25.7 & 51.8 & ND & 35.1 & 642.9 & 0.24 \\
\hline S6 & 78.8 & 113.6 & 68.1 & 12.5 & 119.8 & 47.4 & 42.9 & ND & 95.3 & 1.3 & 26.7 & 15.5 & 50.6 & 31.8 & 32.3 & 66.5 & 1.1 & 53.3 & 857.4 & 0.47 \\
\hline S7 & 102.4 & 165.7 & 71.0 & 15.7 & 131.2 & 61.4 & 54.0 & ND & 132.9 & 0.5 & 30.9 & 20.7 & 70.2 & 40.1 & 43.4 & 83.1 & 1.8 & 69.5 & 1094.6 & \\
\hline \multicolumn{21}{|c|}{ Mole $\%$} \\
\hline S2 & 9.62 & 13.60 & 7.38 & 1.25 & 14.12 & 6.35 & 4.64 & 0.19 & 12.63 & 0.26 & 3.00 & 0.50 & 6.38 & 3.57 & 3.69 & 7.33 & ND & 5.48 & & \\
\hline S3 & 11.48 & 13.66 & 6.63 & 1.46 & 12.28 & 6.11 & 5.08 & ND & 12.33 & 0.02 & 2.81 & 0.74 & 6.22 & 3.53 & 3.54 & 7.23 & 0.19 & 6.68 & & \\
\hline S4 & 9.80 & 12.72 & 6.78 & 1.14 & 14.58 & 6.08 & 4.81 & 0.07 & 12.61 & 0.21 & 2.86 & 0.38 & 6.50 & 3.61 & 4.02 & 7.21 & 0.09 & 6.50 & & \\
\hline S5 & 8.65 & 12.74 & 6.85 & 1.35 & 12.96 & 6.16 & 4.94 & 0.05 & 12.49 & 0.47 & 3.18 & 2.16 & 6.62 & 3.86 & 3.99 & 8.06 & ND & 5.46 & & \\
\hline S6 & 9.19 & 13.25 & 7.94 & 1.46 & 13.97 & 5.53 & 5.00 & ND & 11.11 & 0.15 & 3.12 & 1.81 & 5.90 & 3.71 & 3.76 & 7.76 & 0.12 & 6.22 & & \\
\hline S7 & 8.77 & 14.06 & 6.23 & 1.37 & 12.24 & 5.51 & 5.25 & 0.03 & 12.81 & 0.06 & 2.76 & 2.18 & 6.35 & 3.63 & 4.15 & 7.91 & 0.09 & 6.58 & & \\
\hline
\end{tabular}

S7 and may have been present in other samples but in concentrations below our detection limit.

\section{Discussion}

\subsection{Eddy-field influence on organic matter fluxes}

Several previous studies have focused on the changes induced by eddies on nutrient distributions, primary production, phytoplankton composition and organic matter export (Jeffrey and Hallegraeff, 1980; Falkowski et al., 1991; McGillicuddy et al., 1998; Garçon et al., 2001; Bidigare et al., 2003; Rodríguez et al., 2003; Benitez-Nelson et al., 2007; Maiti et al., 2008). These studies show the sequence of processes induced by cyclonic eddies in the ocean: upward displacement of isopycnal surfaces, nutrient injection into the euphotic zone, enhancement of phytoplankton growth, changes in plankton community structure, and differential effect on total particle export. However, there is little discussion of the variability in the composition of the exported organic matter, which can be used as a tracer of export and remineralization processes.

Our study reveals that bulk organic matter (POC and PON) fluxes were substantially influenced by the presence of the mesoscale eddy field south of the Canary Islands. In August, carbon and nitrogen exports within eddy-field stations were approximately 1.7 and 2 fold higher, respectively, than those measured at FF stations. During the bloom period (February), the only cyclonic eddy (CE2) sampled also had 2.3fold higher POC export compared to ambient waters not affected by mesoscale eddies (including upwelling stations). These results indicate that the eddy field generated south of the Canary Islands may increase carbon export with respect 
Table 7. Prokaryotic abundance (PA) determined by flow cytometry in water samples from surface to $200 \mathrm{~m}$ during August 2006 and February 2007. S2, S3, S4 and S5 correspond with "coastal” stations while S6 and S7 stand for oceanic stations.

\begin{tabular}{ccccccc}
\hline \multicolumn{7}{c}{ PA $\left(\times 10^{5}\right.$ cells ml $\left.{ }^{-1}\right)$} \\
\hline Depth $(\mathrm{m})$ & FF1 & FF2 & AE1 & AE2 & CE1 & \\
\hline 5 & 3.54 & 3.17 & 7.78 & 3.70 & 4.88 & \\
DCM & 0.95 & 2.88 & 3.57 & 2.78 & 2.72 & \\
125 & 0.68 & 1.80 & 4.89 & 3.31 & 1.87 & \\
200 & 0.61 & 0.78 & 1.54 & 1.13 & 1.01 & \\
\hline Average & $1.44 \pm 1.4$ & $2.16 \pm 1.0$ & $4.44 \pm 2.6$ & $2.73 \pm 1.1$ & $2.62 \pm 1.7$ & \\
\hline Depth (m) & S2 & S3 & S4 & S5 & S6 & S7 \\
\hline 5 & 5.30 & 8.14 & 5.44 & 12.1 & 5.09 & 4.27 \\
DCM & 2.81 & 8.21 & 6.11 & 6.48 & 2.90 & 3.08 \\
125 & 1.98 & 2.49 & 2.68 & 1.83 & 1.38 & 1.34 \\
200 & 1.28 & 1.78 & 1.94 & 1.36 & 1.38 & 1.24 \\
\hline Average & $2.84 \pm 1.7$ & $5.15 \pm 3.5$ & $4.04 \pm 2.0$ & $5.45 \pm 5.0$ & $2.69 \pm 1.7$ & $2.48 \pm 1.4$ \\
\hline
\end{tabular}

to surrounding waters by $>2$ times. Our observations are different from results obtained in cyclonic eddies at the lee of Hawaii, which showed strong silica export (Benitez-Nelson et al., 2007) but no evidence of enhanced particulate carbon export (Benitez-Nelson and McGillicuddy, 2008; Buesseler et al., 2008; Verdeny et al., 2008). The difference in the biogenic silica export could be explained by the silicate distribution. On average, the nutrient source waters in the Pacific have higher ratios of silicic acid to nitrate and phosphate than those in the Atlantic (Ragueneau et al., 2000). Thus, diatoms would be favored in the opal-dominated Pacific Ocean relative to the carbonate-dominated Atlantic Ocean.

Why then does the Canary Island eddy field show enhanced POC export? To try to answer this question we first analyzed the fluxes and composition of chloropigments and amino acids within eddy-field and FF stations.

Total chloropigment fluxes within eddy-field stations were up to an order of magnitude higher than in FF stations. Since pigments are originally derived from surface phytoplankton, we may hypothesize that eddies enhance both primary production and sinking fluxes in this region. Alternatively, the higher pigment fluxes within eddy-field stations could originate from a lower pigment degradation rate relative to surrounding waters, although in this case, a lower prokaryotic abundance (PA) would be expected. However, the August eddies had 2 times higher PA compared to station FF stations (Table 7). Looking at the differences in chloropigment compositions between eddy-field and FF stations, we found that chl $a$ is the dominant pigment within eddies, while at FF stations, pheophytin- $a$ was dominant. Higher chlorophyll enrichment reflects "fresher" material within eddies, while at FF stations a higher proportion of pheophytin- $a$ illustrated the more important role of microbes and microzooplankton in organic matter degradation (Shuman and Lorenzen, 1975; Sun et al., 1993; Strom, 1993). The absence or very low fluxes of pheophorbide- $a$ and pyropheophorbide- $a$ at both FF and eddy-field stations indicate a minimum impact of grazing by mesozooplankton (Shuman and Lorenzen, 1975; Ziegler et al., 1988). Low pheopigment fluxes have been previously reported in the NE subarctic Pacific where the impact of mesozooplankton herbivory was negligible during summer (Thibault et al., 1999).

Total average amino acid fluxes within cyclonic and anticyclonic eddy-field stations were 2-fold higher than in FF stations, similar to POC flux, which is in agreement with the fact that a significant fraction of POC in surface waters consists of amino acids (Lee et al., 2004). Additionally, the comparison of the amino acids carbon content with respect to the total POC (AA-C/POC) give direct information on the contribution of THAA to the total POC flux. Table 5 shows an enhanced AA-C/POC within eddies, except at AE1, suggesting that the high POC flux observed in this station must come from other compounds. As is the case for chloropigments, the higher amino acid fluxes within eddy-field relative to FF stations are likely to be a result of enhanced primary production in the mesoscale structures caused by nutrient pumping. Although amino acid compositions are generally similar in both eddy-field and FF samples (Table 5), there are some marked differences. We used Principal Components Analysis (PCA) on a data set that included compositions (in mole \%) of amino acids and chloropigments at FF and eddyfield stations with the aim of correlating differences in amino acid compositions with degradation state and source of organic matter (Fig. 5a). Often, the first principal component (PC1) is associated with the degradation index of organic matter (Dauwe and Middelburg, 1998), but the source can be 

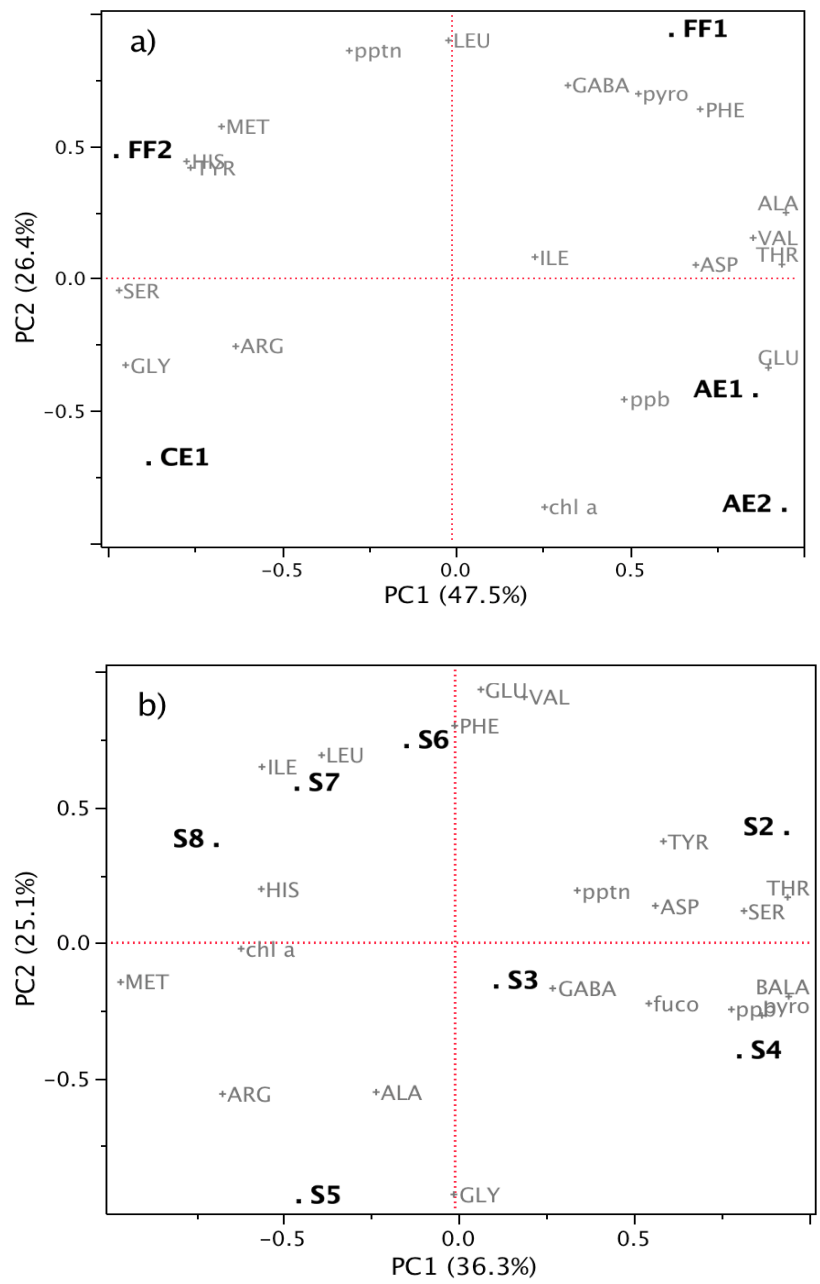

Fig. 5. Principal components analysis (PCA) comparing: (a) eddyfield and far-field stations and (b) S station samples. The data set used included mole $\%$ of individual amino acids and chloropigments. The first two principal components (PC1 and PC2) explain most of the variance in the data set. See Tables 2 and 5 for pigments and amino acids names, respectively.

just as important as decomposition (Sheridan et al., 2002; Ingalls et al., 2006). In our case, the first principal component (PC1) indicates that the two FF stations differ in organic matter source. FF2 was enriched in glycine and serine, suggesting the presence of diatoms. FF1 was more enriched in aspartic and glutamic acids and $\gamma$-aminobutyric acid (GABA), suggesting a mixture of fresh calcium-carbonate associated organic matter and microbially degraded organic matter (Table 3). The second principal component (PC2) appeared to be related to organic matter degradation state, with pheophytin and GABA at the top and chl $a$ towards the bottom of the PCA. There was a clear difference between eddy-field (negative site scores) and FF stations (positive site scores), consistent with the idea that there was more degraded organic matter at FF than at eddy-field stations (Fig. 5a).
Our amino acid and chloropigment compositional data indicate low impact of grazing by micro and mesozooplankton within eddy-field stations (Tables 5 and 2). Therefore, the more likely fate of the organic matter produced by the eddy-field stations is downward export out of the euphotic zone as macroaggregates. This hypothesis is also corroborated by the current knowledge of the phytoplankton community structure of this area. The phytoplankton biomass of this region is dominated by small size cells such as picoplankton and flagellates (Head et al., 2002; Arístegui et al., 2004) and calcium-carbonate producing organisms (Fischer et al., 1996; Abrantes et al., 2002). These latter authors found that the composition of the sinking matter collected in deep sediment traps in the Canary region was dominated by coccolithophorids, which were found in both fecal pellets and aggregates all year round. Based on sediment trap data, Klaas and Archer (2002) suggest a more efficient transport of POC through the mesopelagic waters in "calcifying" regions. Ingalls et al. (2006) also suggested that, in diatom-rich areas, the grazing pressure by mesozooplankton is higher than in $\mathrm{CaCO}_{3}$-rich areas, and that the latter areas would have higher aggregate export instead of fecal pellet production. Indeed, Head et al. (2002) concluded that, with small size cells dominating phytoplankton biomass, only $15 \%$ of the carbon in phytoplankton standing stock could be directly used by mesozooplankton grazers.

Returning back to the question posed at the beginning of this discussion, we hypothesize that the impact of zooplankton grazing caused the difference in the relative export fluxes between eddies of Hawaii and Sargasso Sea (E-Flux and EDDIES programes) and the Canary Islands. In Hawaiian and Sargasso Sea eddies, zooplankton grazing was observed to be an important process controlling diatom blooms inside eddies (Benitez-Nelson and McGillicuddy, 2008; Goldthwait and Steinberg, 2008; Landry et al., 2008; Maiti et al., 2008). On the contrary, our results suggest that zooplankton grazing pressure had a minimum impact in the Canary Island eddy field. Indeed, Hernández-León et al. (2001) found a much lower zooplankton biomass in the core of a cyclonic eddy generated south of the Canary Islands compared to waters outside the eddy. Our findings are consistent with the hypothesis proposed by the above programs of zooplankton grazing as a mechanism to reduce POC export within eddies. However, based on our PCA analysis, we also suggest that phytoplankton community structure, particularly diatom-rich vs. $\mathrm{CaCO}_{3}$-rich, is a major factor influencing the zooplankton grazing pressure and subsequent organic matter export within the eddy-field stations. Moreover, our amino acid compositional data are in agreement with a highly carbonate-ballasted organic matter. In the last decade, several works have indicated that a significant fraction of organic matter produced in surface waters is transported to depth associated with mineral ballast (Armstrong et al., 2002; Francois et al., 2002), and specially with carbonate (Klaas and Archer, 2002). Therefore, the enhanced POC flux observed in the eddies generated 
south of the Canary Islands could be due to the increased particle settling velocity in highly carbonate-ballasted systems in comparison to those in opal-ballasted system (like Hawaii) as also suggested by a recent study off Cape Blanc (Iversen et al., 2010).

\subsection{Cyclonic vs. anticyclonic eddies}

In order to determine biogeochemical differences between eddies, we compared bulk organic matter export in combination with pigment and amino acid compositions and fluxes. Since the anticyclonic eddy AE2 was sampled during its early formation state (close to the coast of Gran Canaria Island), we focused our comparative analysis on the anticyclonic AE1 and cyclonic CE1 eddies. POC fluxes were 1.3 fold higher within AE1 relative to CE1, while PON fluxes were similar. Thus $\mathrm{C} / \mathrm{N}$ ratios were higher (12.8) at $\mathrm{AE} 1$ than at CE1 (8.2). Although these total organic carbon and nitrogen values are useful, knowledge of the specific compounds provides us with better information about the different types of eddies.

Comparing total amino acid fluxes between eddies, we found that CE1 had a 2-fold higher total amino acid flux than AE1. Within cyclonic eddies an upward displacement of nutrient-rich isopycnal surfaces occurs, presumably yielding an external source of nutrients from the thermocline to the euphotic zone (McGillicuddy and Robinson, 1997). On average, the supply of nitrate to the euphotic zone would be balanced by the export of organic nitrogen contained mainly in sinking particles exported to the mesopelagic zone. Therefore, the greater THAA flux at CE1 eddy station relative to AE1 eddy is consistent with a higher surface new primary production reaching the trap as a result of a nutrient enrichment of surface waters. The AE1 eddy station presented a higher prokaryotic abundance (PA) than that at CE1 (Table 7). Therefore, the greater THAA flux at CE1 relative to AE1 could be caused by a lower heterotrophic activity at CE1 resulting in a higher fraction of net primary production reaching the trap. This would also explain why $\mathrm{C} / \mathrm{N}$ ratios were lower at CE1 than at AE1.

However, when comparing the total chloropigment fluxes between eddies an opposite pattern to the amino acids is observed. In this case, we found that within AE1 chl $a$ fluxes were 2.4 fold higher than in CE1. Several other studies have found this pattern as well. Moore et al. (2007) found that, based on 6 years of satellite and in situ estimates of $\operatorname{chl} a$, anticyclonic eddies in the Western Australian Coast showed higher phytoplankton biomass than cyclonic. Other studies found that anticyclonic eddies contain relatively elevated chl $a$ concentrations that originated from entrainment (during eddy formation) of water enriched in chl $a$ from the continental shelf or upwelling areas (Arístegui et al., 1997; Ginzburg et al., 2002; Waite et al., 2007). A possible explanation for this counterintuitive result could be associated with the eddy's intrinsic physical structure. Anticyclonic eddies have a deeper mixed layer than cyclonic eddies (Fig. 3a), so vertical mixing is more pronounced (up to 20 times faster and deeper) than in cyclonic eddies, yielding a "vertical" homogeneity (Thompson et al., 2007). Thus, cells are displaced vertically from surface to deeper layers within anticyclonic eddies (see deeper DFM at AE1 relative to CE1, Fig. 3c). Shade-adapted (deeper) cells have higher chl:carbon ratio than sun-adapted (shallower) cells (Falkowski, 1980; Laws and Bannister, 1980; Geider, 1987; Armstrong, 2006), suggesting that at equal carbon export, a higher chl $a$ flux within anticyclonic eddies would occur. An alternative explanation to the observed difference in standing stocks between both eddy types could be related to the eddy/wind interactions. Based on an eddy/wind interaction model, McGillicuddy et al. (2007) predicted a downwelling in the interior of cyclonic eddies, and a divergence in the center of anticyclonic eddies. This situation could led to the enhanced chloropigment flux observed within AE1.

PCA analysis also reveals important differences in amino acid and chloropigment compositions between CE1 and AE1 eddies (Fig. 5a). CE1 was enriched in mole\% serine and glycine suggesting enrichment in diatom-derived organic matter. However, anticyclonic eddies were more enriched in mole $\%$ aspartic and glutamic acids. These two latter amino acids often indicate the presence of $\mathrm{CaCO}_{3}$-forming organisms (Degens, 1976; Carter and Mitterer, 1978; Müller et al., 1986; Lee et al., 2000; Ingalls et al., 2003), suggesting that the dominant phytoplankton organisms within AE1 were coccolithophorids. These organisms tend to thrive in layers of reduced light intensity and low nutrient concentrations, which is in agreement with the deeper DFM of AE1 relative to CE1. Therefore, the greater presence of coccolithophorids in anticyclonic eddies would explain the higher fluxes of chl $a$ and aspartic and glutamic acid. Regarding organic matter lability, both types of eddies showed similar negative site scores on PC2, suggesting that organic matter exported from $\mathrm{CE} 1$ and $\mathrm{AE} 1$ had similar degradation states.

\subsection{Regional variability in organic matter composition and flux}

Particulate organic carbon fluxes at $200 \mathrm{~m}$ ranged from $\sim 8.5 \mathrm{mmol} \mathrm{C} \mathrm{m}^{-2} \mathrm{~d}^{-1}$ at open ocean stations $\mathrm{S} 6$ and $\mathrm{S} 8$, to $\sim 12 \mathrm{mmol} \mathrm{C} \mathrm{m}^{-2} \mathrm{~d}^{-1}$ at $\mathrm{S} 1$ and $\mathrm{S} 2$ stations located south of the Canary Islands, to $\sim 13 \mathrm{mmol} \mathrm{C} \mathrm{m}^{-2} \mathrm{~d}^{-1}$ at stations $\mathrm{S} 3$, S4 and S5 affected by upwelling. These POC export values are the highest ever reported for this area, probably because it is the first time that they were measured during the phytoplankton bloom period. In autumn, the POC sinking flux, measured with drifting traps at about $200 \mathrm{~m}$, was approximately $0.3 \mathrm{mmol} \mathrm{C} \mathrm{m}^{-2} \mathrm{~d}^{-1}$ at the ESTOC time series station (North of the Canary Islands, Neuer et al., 2007). However, POC fluxes collected with similar traps at 150$200 \mathrm{~m}$, along two coastal-ocean sections ( $26 \mathrm{~N}$ and $21 \mathrm{~N}$ ), during summer and fall, outside the influence of the intense eddy 
field and the coastal upwelling, varied on average from 0.7 to $4.9 \mathrm{mmol} \mathrm{C} \mathrm{m}^{-2} \mathrm{~d}^{-1}$ (J. Arístegui, unpublished). All these results reflect a strong spatio-temporal variability of POC fluxes within this region.

The elemental composition of sinking particulate organic matter was relatively uniform and close to the classical Redfield ratio $(\mathrm{C} / \mathrm{N}=6.4)$ at the upwelling and open ocean stations. However, south of the Canary Islands (S1 and S2 stations) $\mathrm{C} / \mathrm{N}$ ratios were $\sim 9.1$, which is consistent with the high remineralization rates reported for this area (Arístegui et al., 2005). Interestingly, contrary to what might be expected from the August eddy results, the $\mathrm{C} / \mathrm{N}$ ratio in trap material collected at $200 \mathrm{~m}$ in the CE2 eddy was extremely high $(\mathrm{C} / \mathrm{N}=32)$, even higher than at the FF stations during August. Unfortunately, we do not have chloropigment and amino acid data within the CE2 eddy to try to explain this result. However, the CE2 eddy had an extremely strong fluorescence maximum (Fig. 3d) and a high gross primary production rate (Arístegui and Alonso-González, unpublished), so we might expect sinking of fresh phytoplankton-derived material. Thus, assuming that this high $\mathrm{C} / \mathrm{N}$ value is correct, it probably reflects a carbon excess more than the presence of highly refractory organic matter. The molar $\mathrm{C} / \mathrm{N}$ ratios of transparent exopolymer particles (TEP) are generally above the Redfield ratio, with a mean value of 26 (Engel and Passow, 2001). Thus, production of TEP during a bloom condition is one mechanism that could yield such high $\mathrm{C} / \mathrm{N}$ ratio within CE2. Alternatively, the high $\mathrm{C} / \mathrm{N}$ ratios measured at FF stations during August and within CE2 during February may be related to terrestrial organic matter inputs, although we do not have any data supporting this hypothesis.

Chloropigment fluxes clearly showed a decrease with increasing distance from the coast, similar to the POC flux. A simple explanation for this decrease could be that gross primary production was 1.2 to 7 times lower at open ocean stations than at more coastal stations (Arístegui and AlonsoGonzález, unpublished). On the contrary, THAA fluxes did not show as clear a pattern as chloropigments, with high amino acids fluxes at open ocean station S7.

The composition of sinking particulate organic matter showed several differences in the PCA analysis (Fig. 5b). PC1, which explains $36 \%$ of the variance, appears to reflect the organic matter degradation state, with the chl $a$ at the left and the pheophytin and Gaba towards the right of the PCA. PC2 appears to be related to the organic matter source, with glycine at the bottom and glutamic and aspartic acids towards the top of the PCA. Thus stations closer to the coast (S2, S3, S4 and S5) appear to be dominated by diatom, bacterial and zooplankton indicators, suggesting that the organic matter biosynthesized was actively remineralized by heterotrophic organisms. This is corroborated by the significant higher prokaryotic abundance (PA) found in these stations relative to open ocean stations ( $p<0.05$, Table 7). However, the open ocean stations S6, S7 and S8 were more associated with chl $a$ and fresh cytoplasm components, which is in agreement with the low PA observed in this stations (Table 7). Again, the relationship between the magnitude of the fluxes and quality of organic matter suggests that stations with high carbon fluxes present "reworked" material, whereas stations with low carbon fluxes show more "fresh" material. The capture of laterally advected particles from the upwelling margin could be one reason for the lower lability of the coastal samples. If a significant proportion of the particles collected at the coastal station were laterally advected, having a longer residence time in the water column, they might be relatively older compared to the particles traveling vertically. Indeed, recent studies have demonstrated that the lateral transport of particulate material from the African coast is a key process controlling the organic carbon dynamic in this area (Karakas et al., 2006; Alonso-González et al., 2009; Fischer et al., 2009). Another possible explanation for this counterintuitive result could be that in coastal stations the heterotrophic community (particularly mesozooplankton) is more active than in open ocean stations. This hypothesis is supported by the relative enrichment of pheophorbide- $a$ and pyropheophorbide- $a$ in coastal stations, indicating zooplankton grazing activity.

\section{Conclusions}

In summary, we found that the eddy field generated south of the Canary Islands enhanced POC export with respect to open ocean waters by $>2$ times. Flux increases of one order of magnitude in chloropigment and 2 times in THAA are also observed in the eddy-field relative to FF stations. The enhancement of particulate organic matter fluxes by mesoscale eddies in The Canary Islands seems to be related to the low zooplankton grazing pressure. Our findings are consistent with the hypothesis proposed by the E-Flux and EDDIES programs of higher trophic levels reducing POC export within eddies. However, we suggest phytoplankton community structure, particularly diatom-rich vs. $\mathrm{CaCO}_{3}-$ rich organisms, ballasting, and subsequent zooplankton activity as major factors influencing organic matter export within eddies. Overall, eddies during the August period behaved partly like the ambient waters during the bloom period, enhancing POC, PON, amino acid and pigment fluxes. However, several differences were found between the different types of eddies. Cyclonic eddy CE1 had higher total amino acid flux than the anticyclonic eddies, while the contrary is true for pigments. The organic matter composition was different, with the cyclonic eddy more enriched in diatom-derived organic matter and the anticyclonic eddies more enriched in $\mathrm{CaCO}_{3}$-forming organisms. At eddy stations, higher chlorophyll enrichment reflects "fresher" material, while at FF stations a higher proportion of pheophytin illustrates the more important role of microbes and microzooplankton in degrading organic matter. These results suggest that the eddy field generated by the Canary Islands may 
simulate bloom conditions acting as "fresh" organic matter pump to the mesopelagic waters.

Our February POC export values are the highest ever reported for this area, probably as result of measuring fluxes during the phytoplankton bloom period. This large variability must be taken into account in building annual carbon budgets for the region. Both, pigments and THAA compositional changes show that the source of sinking particles varies zonally and meridionally and suggests that sinking particles were more degraded at coastal relative to open ocean stations. The capture of laterally advected particles from the upwelling margin together with an active heterotrophic community at coastal station seem to be the reason for the greater degradation of organic matter in the coastal samples.

Acknowledgements. This work has been supported through the Spanish "Plan Nacional de I+D" (MEC) under the RODA (CTM2004-06842-C03-03/MAR) and CAIBEX (CTM200766408-C02-02) projects. Iván J. Alonso-González was supported by a MEC (FPU) grant. We thank the captain and crew of the $\mathrm{R} / \mathrm{V}$ Hespérides for their support at sea. Special thanks goes to Lynn Abramson for her valuable help with the sample analysis and to Verónica Benitez-Barrios for her comments on this manuscript.

Edited by: K. Suzuki

\section{References}

Abrantes, F., Meggers, H., Nave, S., Bollman, J., Palma, S., Sprengel, C., Henderiks, J., Spies, A., Salgueiro, E., Moita, T., and Neuer, S.: Fluxes of micro-organisms along a productivity gradient in the Canary Islands region $\left(29^{\circ} \mathrm{N}\right)$ : implications for paleoreconstructions, Deep-Sea Res. Pt. II, 49, 3599-3629, 2002.

Alonso-González, I. J., Arístegui, J., Vilas, J. C., and HernándezGuerra, A.: Lateral POC transport and consumption in surface and deep waters of the Canary Current region: a box model study, Global Biogeochem. Cy., 23, GB2007, doi:10.1029/2008GB003185, 2009.

Arístegui, J., Tett, P., Hernández-Guerra, A., Basterretxea, G., Montero, M. F., Wild, K., Sangrá, P., Hernández-León, S., Cantón, M., García-Braun, J. A., Pacheco, M., and Barton, E. D.: The influence of island-generated eddies on chlorophyll distribution: a study of mesoscale variation around Gran Canaria, Deep-Sea Res. Pt. I, 44, 71-96, 1997.

Arístegui, J., Hernández-León, S., Montero, M. F., and Gomez, M.: The seasonal planktonic cycle in coastal waters of the Canary Islands, Sci. Mar., 65, 51-58, 2001.

Arístegui, J., Barton, E. D., Tett, P., Montero, M. F., García-Muñoz, M., Basterretxea, G., Cussatlegras, A., Ojeda, A., and de Armas, D.: Variability in plankton community structure, metabolism, and vertical carbon fluxes along an upwelling filament (Cape Juby, NW Africa), Prog. Oceanogr., 62, 95-113, 2004.

Arístegui, J., Duarte, C. M., Gasol, J. M., and Alonso-Sáez, L.: Active mesopelagic prokaryotes support high respiration in the subtropical north-east Atlantic Ocean, Geophys. Res. Lett., 32, L03608.1-L03608.4, doi:10.1029/2004GL021863, 2005.
Armstrong, R. A., Lee, C., Hedges, J. I., Honjo, S., and Wakeham, S. G.: A new mechanistic model for organic carbon fluxes in the ocean: based on the quantitative association of POC with ballast minerals, Deep-Sea Res. Pt. II, 49, 219-236, 2002.

Armstrong, R. A.: Optimality-based modeling of nitrogen allocation and photoacclimation in photosynthesis, Deep-Sea Res. Pt. II, 53, 513-531, 2006.

Benitez-Nelson, C., Bidigare, R. R., Dickey, T. D., Landry, M. R., Leonard, C. L., Brown, S. L., Nencioli, F., Rii, Y. M., Maiti, K., Becker, J. W., Bibby, T. S., Black, W., Cai, W. J., Carlson, C. A., Chen, F., Kuwahara, V. S., Mahaffey, C., McAndrew, P. M., Quay, P. D., Rappe, M. S., Selph, K. E., Simmons, M. P., and Yang E. J.: Mesoscale eddies drive increased silica export in the subtropical Pacific Ocean, Science, 316, 1017-1020, 2007.

Benitez-Nelson, C. R. and McGillicuddy, D. J.: Mesoscale physical-biological-biogeochemical linkages in the open ocean: an introduction to the results of the E-Flux and EDDIES Programs, Deep-Sea Res. Pt. II, 55, 1133-1138, 2008.

Bidigare, R. R., Benitez-Nelson, C., Leonard, C. L., Quay, P. D., Parsons, M. L., Foley, D. G., and Seki, M. P.: Influence of a cyclonic eddy on microheterotroph biomass and carbon export in the lee of Hawaii, Geophys. Res. Lett., 30, 1318, doi:10.1029/2002GL016393, 2003.

Buesseler, K. O., Lamborg, C., Cai, P., Escoube, R., Johnson, R., Pike, S., Masque, P., McGillicuddy, D., and Verdeny, E.: Particle fluxes associated with mesoscale eddies in the Sargasso Sea, Deep-Sea Res. Pt. II, 55, 1426-1444, 2008.

Dauwe, B. and Middelburg, J.: Amino acids and hexosamines as indicators of organic matter degradation state in North Sea sediments, Limnol. Oceanogr., 43, 782-798, 1998.

Dauwe, B., Middelburg, J. J., Herman, P. M. J., and Heip, C. H. R.: Linking diagenetic alteration of amino acids and bulk organic matter reactivity, Limnol. Oceanogr., 44, 1809-1814, 1999.

Engel, A. and Passow, U.: Carbon and nitrogen content of transparent exopolymer particles (TEP) in relation to their Alcian Blue adsorption, Mar. Ecol.-Prog. Ser., 219, 1-10, 2001.

Falkowski, P. G.: Light-shade adaptation in marine phytoplankton, in: Primary productivity in the sea, edited by: Falkowski, P. G., Plenum Press, New York, 531 pp., 1980.

Falkowski, P. G., Ziemann, D., Kolber, Z., and Bienfang, P. K.: Role of eddy pumping in enhancing primary production in the ocean, Nature, 352, 55-58, 1991.

Fischer, G., Neuer, S., Krause, G., and Wefer, G.: Short-term sedimentation pulses recorded with a fluorescence sensor and sediment traps in $900 \mathrm{~m}$ water depth in the Canary basin, Limnol. Oceanogr., 41, 1354-1359, 1996.

Fischer, G., Reuter, C., Karakas, G., Nowald, N., and Wefer, G.: Offshore advection of particles within the Cape Blanc filament, Mauritania: results from observational and modelling studies, Prog. Oceanogr., 83, 322-330, 2009.

Francois, R., Honjo, S., Krishfield, R., and Manganini, S.: Factors controlling the flux of organic carbon in the bathypelagic ocean, Global Biogeochem. Cy., 16(4), 1087, doi:10.1029/2001GB001722, 2002.

Garçon, V. C., Oschlies, A., Doney, S. C., McGillicuddy, J., and Waniek, J.: The role of mesoscale variability on plankton dynamics in the North Atlantic, Deep-Sea Res. Pt. II, 48, 2199-2226, 2001. 
Geider, R. J.: Light and temperature dependence of the carbon to chlorophyll ratio in microalgae and cyanobacteria: implications for physiology and growth of phytoplankton, New Phytol., 106, 1-34, 1987.

Ginzburg, A. I., Kostianoy, A. G., Nezlin, N. P., Soloviev, D. M., and Stanichny, S. V.: Anticyclonic eddies in the northwestern Black Sea, J. Mar. Syst., 32, 91-106, 2002.

Goldthwait, S. and Steinberg, D.: Elevated biomass of mesozooplankton and enhanced fecal pellet flux in cyclonic and modewater eddies in the Sargasso Sea, Deep-Sea Res. Pt. II, 55, 13601377, 2008.

Goñi, M. A., Yunker, M. B., Macdonald, R. W., and Eglinton, T. I.: Distribution and sources of organic biomarkers in Arctic sediments from the Mackenzie River and Beaufort shelf, Mar. Chem., 71, 23-51, 2000.

Goutx, M., Guigue, C., Leblond, N., Desnues, A., Dufour, A., Aritio, D., and Guieu, C.: Particle flux in the northeast Atlantic Ocean during the POMME experiment (2001): Results from mass, carbon, nitrogen, and lipid biomarkers from the drifting sediment traps, J. Geophys. Res., 110, C07S20, doi:10.1029/2004JC002749, 2005.

Goutx, M., Wakeham, S. G., Lee, C., Duflos, M., Guigue, C., Liu, Z., Moriceau, B., Sempèrè, R., Tedetti, M., and Xue, J.: Composition and degradation of marine particles with different settling velocities in the northwest Mediterranean Sea, Limnol. Oceanogr., 52, 1645-1664, 2007.

Head, R. N., Medina, G., Huskin, I., Anadon, R., and Harris, R. P.: Phytoplankton and mesozooplankton distribution and composition during transects of the Azores subtropical front, Deep-Sea Res. Pt. II, 49, 4023-4034, 2002.

Hernández-León, S., Gómez, M., Pagazaurtundua, M., PortilloHahnefeld, A., Montero, I., and Almeida, C.: Vertical distribution of zooplankton in Canary Island waters: implications for export flux, Deep-Sea Res. Pt. I, 48, 1071-1092, 2001.

Hernández-León, S., Gómez, M., and Arístegui, J.: Mesozooplankton in the Canary Current System: The coastal-ocean transition zone, Prog. Oceanogr., 74, 397-421, 2007.

Heussner, S., Ratti, C., and Carbonne, J.: The PPS 3 time-series sediment trap and the trap sample processing techniques used during the ECOMARGE experiment, Cont. Shelf Res., 10, 943958, 1990.

Ingalls, A. E., Liu, Z., and Lee, C.: Seasonal trends in the pigment and amino acid compositions of sinking particles in biogenic $\mathrm{CaCO}_{3}$ and $\mathrm{SiO}_{2}$ dominated regions of the Pacific sector of the Southern Ocean along $170^{\circ} \mathrm{W}$, Deep-Sea Res. Pt. I, 53, 836-859, 2006.

Iversen, M. H., Nowald, N., Ploug, H., Jackson, G. A., and Fischer, G.: High resolution profiles of vertical particulate organic matter export off Cape Blanc, Mauritania: Degradation processes and ballasting effects, Deep-Sea Res. Pt. I, 57, 771-784, 2010.

Jeffrey, S. W. and Hallegraeff, G. M.: Studies of phytoplankton species and photosynthetic pigments in a warm-core eddy of the East Australian Current, I. Summer populations, Mar. Ecol.Prog. Ser., 3, 285-294, 1980.

King, L. L.: Chlorophyll diagenesis in the water column and sediment of the Black Sea, Ph. D. Thesis, Massachusetts Institute of Technology, 1993.
Klaas, C. and Archer, D. E.: Association of sinking organic matter with various types of mineral ballast in the deep sea: Implications for the rain ratio, Global Biogeochem. Cy., 16, 1116, doi:10.1029/2001GB001765, 2002.

Knauer, G. A., Martin, J. H., and Bruland, K. W.: Fluxes of particulate carbon, nitrogen, and phosphorus in the upper water column of the northeast Pacific, Deep-Sea Res., 26, 97-108, 1979.

Landry, M. R., Decima, M., Simmons, M. P., Hannides, C. C. S., and Daniels, E.: Mesozooplankton biomass and grazing responses to Cyclone Opal, a subtropical mesoscale eddy, DeepSea Res. Pt. II, 55, 1378-1388, 2008.

Laws, E. A. and Bannister, T. T.: Nutrient and light-limited growth of Thalassiosira fluviatilis in continuous culture, with implications for phytoplankton growth in the ocean, Limnol. Oceanogr., 25, 457-473, 1980.

Lee, C. and Cronin, C.: The vertical flux of particulate nitrogen in the sea: Decomposition of amino acids in the Peru upwelling area and the equatorial Atlantic, J. Mar. Res., 40, 227-251, 1982.

Lee, C. and Cronin, C.: Particulate amino acids in the sea: Effects of primary productivity and biological decomposition, J. Mar. Res., 42, 1075-1097, 1984.

Lee, C., Wakeham, S. G., and Hedges, J. I.: Composition and flux of particulate amino acids and chloropigments in equatorial Pacific seawater and sediments, Deep-Sea Res. Pt. I, 47, 1535-1568, 2000.

Lee, C., Wakeham, S., and Arnosti, C.: Particulate organic matter in the sea: the composition conundrum, Ambio, 33, 565-575, 2004.

Lindroth, P. and Mopper, K.: High-performance liquid chromatographic determination of subpicomole amounts of amino acids by precolumn fluorescence derivatization with ophthaldialdehyde, Anal. Chem., 51, 1667-1674, 1979.

Maiti, K., Benitez-Nelson, C., Rii, Y. M., and Bidigare, R. R.: Influence of a mature cyclonic eddy on particulate export in the lee of Hawaii, Deep-Sea Res. Pt. II, 55, 1445-1460, 2008.

McGillicuddy, D. J. and Robinson, A. R.: Eddy induced nutrient supply and new production in the Sargasso Sea, Deep-Sea Res. Pt. I, 44, 1427-1449, 1997.

McGillicuddy Jr., D. J., Robinson, A. R., Siegel, D. A., Jannasch, H. W., Johnson, R., Dickey, T. D., McNeil, J., Michaels, A. F., and Knap, A. H.: Influence of mesoscale eddies on new production in the Sargasso Sea, Nature, 394, 263-266, 1998.

McGillicuddy, D. J., Anderson, L. A., Bates, N. R., Bibby, T., Buesseler, K. O., Carlson, C. A., Davis, C. S., Ewart, C., Falkowski, P. G., Goldthwait, S. A., Hansell, D. A., Jenkins, W. J., Johnson, R., Kosnyrev, V. K., Ledwell, J. R., Li, Q. P., Siegel, D. A., and Steinberg, D. K.: Eddy/Wind Interactions Stimulate Extraordinary Mid-Ocean Plankton Blooms, Science, 316, 1021-1026, 2007.

Moore, T. S., Matear, R. J., Marra, J., and Clementson, L.: Phytoplankton variability off the Western Australian Coast: Mesoscale eddies and their role in cross-shelf Exchange, Deep-Sea Res. Pt. II, 54, 943-960, 2007.

Moran, S. B., Charette, M. A., Pike, S. M., and Wicklund, C. A.: Differences in seawater particulate organic carbon concentration in samples collected using small- and large-volume methods: the importance of DOC adsorption to the filter blank, Mar. Chem., 67, 33-42, 1999. 
Neuer, S., Cianca, A., Helmke, P., Freudenthal, T., Davenport, R., Meggers, H., Knoll, M., Santana-Casiano, J. M., GonzálezDávila, M., Rueda, M. J., and Llinás, O.: Biogeochemistry and hydrography in the eastern subtropical North Atlantic gyre, Results from European time-series station ESTOC, Prog. Oceanogr., 72, 1-29, 2007.

Olaizola, M., Ziemann, D. A., Bienfang, P. K., Walsh, W. A., and Conquest, L. D.: Eddy-induced oscillations of the pycnocline affect the floristic composition and depth distribution of phytoplankton in the subtropical Pacific, Mar. Biol., 116, 533-542, 1993.

Ragueneau, O. Tréguer, P., Leynaert, A., Anderson, R. F., Brzezinsnki, M. A., DeMaster, D. J., Dugdale, R. C., Dymond, J., Fischer, G., François, R., Heinze, C., Maier-Reimer, E., MartinJézéquel, V., Nelson, D. M., and Quéguiner, B.: A review of the Si cycle in the modern ocean: recent progress and missing gaps in the application of biogenic opal as a paleoproductivity proxy, Global Planet. Change, 26, 317-365, 2000.

Rodríguez, F., Varela, M., Fernandez, E., and Zapata, M.: Phytoplankton and pigment distributions in an anticyclonic slope water oceanic eddy (SWODDY) in the southern Bay of Biscay, Mar. Biol., 143, 995-1011, 2003.

Sánchez-Vidal, A., Calafat, A., Canals, M., and Fabres, J.: Particle fluxes in the Almeria-Oran front: control by coastal upwelling and sea surface circulation, J. Mar. Syst., 52, 89-106, 2004.

Sheridan, C. C., Lee, C., Wakeham, S. G., and Bishop, J. K. B.: Suspended particle organic composition and cycling in surface and midwaters of the equatorial Pacific Ocean, Deep-Sea Res. Pt. I, 49, 1983-2008, 2002.

Shuman, F. R. and Lorenzen, C. J.: Quantitative degradation of chlorophyll by a marine herbivore, Limnol. Oceanogr., 20, 580586, 1975.

Strom, S. L.: Production of pheopigments by marine protozoa: results of laboratory experiments analyzed by HPLC, Deep-Sea Res., 40, 57-80, 1993.

Sun, M. Y., Aller, R. C., and Lee, C.: Early diagenesis of chlorophyll- $a$ in Long Island Sound: a measure of carbon flux and particle reworking, J. Mar. Res., 49, 379-401, 1991.

Sun, M.-Y., Lee, C., and Aller, R. C.: Anoxic and oxic degradation of ${ }^{14} \mathrm{C}$-labeled chloropigments and a ${ }^{14} \mathrm{C}$-labeled diatom in Long Island Sound sediments, Limnol. Oceanogr., 38, 14381451, 1993.
Sweeney, E. N.: Monthly variability in upper ocean biogeochemistry due to mesoscale eddy activity in the Sargasso Sea, P.h.D. thesis, Mass. Inst. of Technol./Woods Hole Oceanogr. Inst., Join Program, 2001.

Thompson, P. A., Pesant, S., and Waite, A. M.: Contrasting the vertical differences in the phytoplankton biology of a dipole pair of eddies in the south-eastern Indian Ocean, Deep-Sea Res. Pt. II, 54, 1003-1024, 2007.

Thibault, D., Roy, S., Wong, C. S., and Bishop, J. K.: The downward flux of biogenic material in the NE subarctic Pacific: importance of algal sinking and mesozooplankton herbivory, Deep-Sea Res. Pt. II, 46, 2669-2697, 1999.

Tolosa, I., Vescovali, I., LeBlond, N., Marty, J.-C., de Mora, S., and Prieur, L.: Distribution of pigment and fatty acid biomarkers in particulate matter from the frontal structure of the Alboran Sea (SW Mediterranean Sea), Mar. Chem., 88, 103-125, 2004.

Tolosa, I., Leblond, N., Marty, J.-C., de Mora, S., and Prieur, L.: Export fluxes of organic carbon and lipid biomarkers from the frontal structure of the Alboran Sea (SW Mediterranean Sea) in winter, J. Sea Res., 54, 125-142, 2005.

Turnewitsch, R., Springer, B. M., Kiriakoulakis, K., Vilas, J. C., Arístegui, J., Wolff, G., Peine, F., Werk, S., Graf, G., and Waniek, J. J.: Determination of particulate organic carbon (POC) in seawater: The relative methodological importance of artificial gains and losses in two glass-fiber-filter-based techniques, Mar. Chem., 105, 208-228, 2007.

UNESCO: Protocols for the Joint Global Ocean Flux Study (JGOFS) Core Measurement, Intergovernmental Oceanographic Commission, Manual and Guides, 29, 169 pp., 1994.

Verdeny, E., Masqué, P., Maiti, K., Garcia-Orellana, J., Bruach, J. M., and Benitez-Nelson, C. R.: Particle export within cyclonic Hawaiian lee eddies derived from ${ }^{210} \mathrm{~Pb}^{210}$ Po disequilibria, Deep-Sea Res. Pt. II, 55, 1461-1472, 2008.

Waite, A. M., Pesant, S., Griffin, D. A., Thompson, P. A., and Holl, C. M.: Oceanography, primary production and dissolved inorganic nitrogen uptake in two Leeuwin Current eddies, Deep-Sea Res. Pt. II, 54, 981-1002, 2007

Wakeham, S. G., Lee, C., Hedges, J. I., Hernes, P. J., and Peterson, M. L.: Molecular indicators of diagenetic status in marine organic matter, Geochim. Cosmochim. Ac., 61, 5363-5369, 1997.

Ziegler, R., Blaheta, A., Guha, N., and Schönegge, B.: Enzymatic formation of pheophorbide and pyropheophorbide during chlorophyll degradation in a mutant of Chlorella fusca SHIHIRA et KRAUS, Plant Physiol., 132, 327-332, 1988. 